\title{
Effect of total peony glucoside pretreatment on NF-kB and ICAM-1 expression in myocardial tissue of rat with myocardial ischemia-reperfusion injury
}

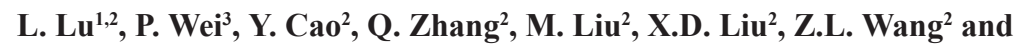
P.Y. Zhang, ${ }^{1,3}$

${ }^{1}$ The First College of Clinical Medicine, Nanjing University of Chinese Medicine, Nanjing, Jiangsu, China ${ }^{2}$ Department of Cardiology, Xuzhou City TCM Hospital, Xuzhou, Jiangsu, China ${ }^{3}$ Department of Cardiology, Xuzhou Central Hospital, Xuzhou, Jiangsu, China

Corresponding author: P.Y. Zhang

E-mail: xiangsingcheng@sina.com

Genet. Mol. Res. 15 (4): gmr15048978

Received July 20, 2016

Accepted September 14, 2016

Published November 3, 2016

DOI http://dx.doi.org/10.4238/gmr15048978

Copyright $(2016$ The Authors. This is an open-access article distributed under the terms of the Creative Commons Attribution ShareAlike (CC BY-SA) 4.0 License.

\begin{abstract}
Early recovery of myocardial perfusion is beneficial for myocardial ischemia. However, ischemia-reperfusion (I/R) may exacerbate myocardial injury. Research shows that total peony glucoside (TPG) can inhibit ischemic myocardial cell apoptosis. However, whether it can ameliorate $\mathrm{I} / \mathrm{R}$ injury remains poorly understood. This study explored the effect of TPG pretreatment on $\mathrm{I} / \mathrm{R}$, through nuclear factor-kappa B (NF-kB) and intercellular adhesion molecule-1 (ICAM1) expressions in $I / R$-affected myocardium. Healthy 7 -week-old male Sprague Dawley rats were randomly categorized into sham operation (A), modeling (B), and 100, 200, and $400 \mathrm{mg} / \mathrm{kg}$ TPG pretreatment
\end{abstract}


groups $(\mathrm{C}, \mathrm{D}$, and $\mathrm{E}$, respectively), with 20 rats in each group. I/R rat models were designed by ligating left anterior descending coronary artery for $30 \mathrm{~min}$ to induce ischemia and for $120 \mathrm{~min}$ to induce reperfusion. Serum interleukin 6 (IL-6) and interleukin 8 (IL-8) levels were measured using enzyme linked immunosorbent assay. NF- $\kappa B$ and ICAM-1 mRNA and protein expressions were detected through RT-PCR and western blot analysis, respectively. Compared to group A, serum IL-6 and IL-8 levels of group B elevated significantly ( $\mathrm{P}<$ $0.05)$, whereas NF- $\mathrm{kB}$ and ICAM-1 mRNA and protein expressions increased in the myocardium $(\mathrm{P}<0.05)$. Serum IL-6 and IL-8 levels, and NF- $\mathrm{\kappa B}$ and ICAM-1 mRNA and protein expressions, in myocardium of TPG groups reduced in a dose-dependent manner. Therefore, TPG pretreatment could alleviate myocardium reperfusion injury in $\mathrm{I} / \mathrm{R}$ rat models by reducing NF- $\mathrm{\kappa B}$ and ICAM- 1 mRNA and protein expressions and cytokine secretions. This mechanism could be associated with the inhibition of NF- $\mathrm{\kappa B}$ activation and downregulation of ICAM-1 expression.

Key words: Total peony glycoside; Myocardial ischemia-reperfusion; NF-кB; ICAM-1; IL-6; IL-8

\section{INTRODUCTION}

Fast, effective recovery of the coronary blood flow, after myocardial ischemia, is an effective method to treat this ischemia. However, myocardial ischemia-reperfusion (I/R) can aggravate ischemia-induced cardiac dysfunction and myocardial cell damage, leading to intracellular calcium overload, apoptosis, and inflammation. Therefore, clarifying its mechanism is important for the prevention of myocardial I/R injury.

Nuclear factor-kappa B (NF- $\mathrm{BB})$ has multidirectional regulatory effects on a large variety of inflammatory mediators, cytokines, and chemokines, such as interleukin 8 (IL8), interleukin 6 (IL-6), and intercellular adhesion molecule-1 (ICAM-1). NF-кB plays critical roles in the regulation of inflammation and cell apoptosis. Even though several signaling pathways, such as nuclear factor erythroid 2 (Nrf2) (Wu et al., 2015) and cAMPdependent protein kinase signaling (Wu et al., 2016), have been identified to be involved in the pathogenesis of $\mathrm{I} / \mathrm{R}, \mathrm{NF}-\mathrm{\kappa B}$ signaling has been demonstrated to be closely associated with myocardial I/R (Liang et al., 2014; Lungkaphin et al., 2015). Myocardial I/R-induced calcium overload and oxidative stress can activate the NF- $\mathrm{KB}$ signaling pathway.

Total peony glycoside (TPG) is a type of monoterpene, extracted from the root of common peony (Paeonia officinalis), with various kinds of pharmacological properties including anti-atherosclerotic, anticoagulant, and antithrombotic (Chen et al., 2012; Xu et al., 2012). It protects the $\mathrm{I} / \mathrm{R}$-affected brain tissue by increasing superoxide dismutase activity, reducing malondialdehyde content, and alleviating ischemic brain tissue edema (Long et al., 2012; Jin et al., 2014). In addition, it can prevent myocardial ischemic cell apoptosis, induced by isopropyl noradrenaline, possibly by inhibiting the expression of Bax and inducing Bcl-2 expression. However, it is not known whether TPG can ameliorate myocardial I/R. Furthermore, considering the involvement of NF- $\mathrm{KB}$ and ICAM-1 in the pathogenesis

Genetics and Molecular Research 15 (4): gmr15048978 
of myocardial I/R, whether TPG could affect the expressions of NF- $\kappa \mathrm{B}$ and ICAM-1 also remains unclear. Therefore, this study aimed to investigate the effect of TPG pretreatment on rat myocardial I/R injury, and its related mechanism, by evaluating NF- $\kappa \mathrm{B}$ and ICAM-1 expressions.

\section{MATERIAL AND METHODS}

\section{Materials}

\section{Experimental animal grouping}

Healthy 7-week-old male Sprague Dawley rats (220-250 g) were provided by the Laboratory Animals Center, Nanjing University of Chinese Medicine (license No. SCXK army 2002-001). The rats were kept and fed in a specific-pathogen-free laboratory, according to the experimental animal standards. The rats were randomly divided into control group (A), model group (B), and 100, 200, and $400 \mathrm{mg} / \mathrm{kg}$ TPG pretreatment groups (C, D, and E, respectively), with 20 rats in each group. TPG was given to the rats 3 days before modeling through intragastric administration, twice a day, and was continued for 3 days after successful modeling at $1 \mathrm{~mL} / 100 \mathrm{~g}$. The rats in groups $\mathrm{A}$ and $\mathrm{B}$ received equal volume of normal saline.

Rats were used for all experiments, and all procedures were approved by the Animal Ethics Committee of The First College of Clinical Medicine, Nanjing University of Chinese Medicine.

\section{Experimental drugs and reagents}

TPG, triphenyl tetrazolium chloride (TTC), and urethane chloride were purchased from Sigma-Aldrich (Carlsbad, CA, USA). TTC $(0.1 \mathrm{~g})$ was dissolved in $5 \mathrm{~mL}$ phosphatebuffered saline for each sample, away from light. IL-6 and IL-8 kits were obtained from Nanjing Jiancheng Bioengineering Institute (Jiangsu, China). Primers for the genes coding NF-кB and ICAM-1 were provided by Invitrogen/Life Technologies (Carlsbad, CA, USA). Primary and secondary antibodies against NF- $\mathrm{KB}$ and ICAM-1 were obtained from ZSBiO BIO, Inc. Co. (Beijing, China).

\section{Experimental methods}

\section{Modeling}

Rat I/R model was designed as described previously (Lungkaphin et al., 2015). Briefly, the rat was anesthetized by abdominal injection with $5 \%$ urethane chloride and a $24 \mathrm{G}$ casing needle was imbedded in its caudal vein. The rat was then fixed in a supine position, and its lead II electrocardiogram (ECG) was monitored. Tracheotomy was performed on the rat and its trachea was connected to a small animal ventilator (tidal volume, $8 \mathrm{~mL} / \mathrm{kg}$; breathing frequency, 70 times/min; inspiration-to-expiration ratio, 1:2). Left common carotid artery was then separated to connect an electrophysiological signal recorder, and the root of the left anterior descending coronary artery was ligated. The rats in the sham operation group underwent threading instead of ligation. The TPG groups underwent ligation for $30 \mathrm{~min}$ to

Genetics and Molecular Research 15 (4): gmr15048978 
induce ischemia and for $2 \mathrm{~h}$ to induce reperfusion, and changes in the ECG were recorded. Ischemia model evaluation: lead II ECG showed ST elevation, or increase in QRS complex amplitude, broadening and fusing with $\mathrm{T}$ wave $5 \mathrm{~min}$ after ligation; decreased arterial blood pressure, $>20 \mathrm{mmHg}$; and cyanosis in vascular ligation-dominated area. Reperfusion model judgment: cyanosis in the ischemic area disappeared; ST elevation decreased, $>50 \%, 30 \mathrm{~min}$ after reperfusion; severe atrioventricular block was eliminated before reperfusion; and mean arterial pressure $<60 \mathrm{mmHg}$ before ligation. The rats were euthanized 4 days after modeling, and their blood and cardiac tissue were collected.

\section{TTC staining to determine infarction area}

The heart was washed with phosphate buffer, and the left ventricle was sliced after it was frozen at $-80^{\circ} \mathrm{C}$ for $5 \mathrm{~min}$. A slice was incubated in $1 \% \mathrm{TTC}$ solution at $\mathrm{pH} 8.5$ for $30 \mathrm{~min}$ at $37^{\circ} \mathrm{C}$. The infarction area showed no coloring, whereas normal tissue was stained reddishbrown. The Image-pro plus6.0 software was used to analyze the infarction area: infarct size in the left ventricle (IS/LV), area at risk in the left ventricle (AAR/LV), and infarct size compared to area at risk (IS/AAR).

\section{Enzyme linked immunosorbent assay (ELISA)}

ELISA was performed to detect serum IL-6 and IL-8 levels, according to the manual.

\section{RT-PCR}

Left ventricle ischemic myocardial tissue was used to extract total RNA using the TransZol Up Plus RNA kit (Cat. No. ER501-01; TransGen Biotech Co. Ltd., Beijng, China). cDNA was synthesized from the RNA for PCR amplification. PCR parameters included initial denaturation at $94^{\circ} \mathrm{C}$ for $3 \mathrm{~min}$, followed by 30 cycles of denaturation at $94^{\circ} \mathrm{C}$ for $30 \mathrm{~s}$, annealing at $56^{\circ} \mathrm{C}$ for $30 \mathrm{~s}$, and extension at $72^{\circ} \mathrm{C}$ for $45 \mathrm{~s}$. $\beta$-actin was selected as a reference, and gel imaging system was used for semi-quantitative analysis, by calculating the absorbance value. The primers used are listed in Table 1.

Table 1. Primer sequences for RT-PCR.

\begin{tabular}{l|c|l|l}
\hline Primer & Length $(\mathrm{bp})$ & Sense & Antisense \\
\hline NF-kB mRNA & 100 & 5'-GAGAGCCCTTGCATCCTTTA-3' & 5'-CTTCCCTTTGGTCTTTCTGT-3' \\
\hline ICAM-1 mRNA & 260 & 5'-CGACTGGACGAGAGGGATTG-3' & 5'-TTATGACTGCGGCTGCTACC-3' \\
\hline$\beta$-actin & 220 & 5'-TGCTGTCCCTGTATGCCTCT-3' & 5'-TTTGATGTCACGCACGATTT-3' \\
\hline
\end{tabular}

\section{Western blot analysis}

Myocardial tissue (100 mg) was lysed using radio-immunoprecipitation assay buffer to extract proteins. Protein concentration was determined by the Bradford method. Proteins were separated by sodium dodecyl sulfate polyacrylamide gel electropheresis (SDS-PAGE) and were transferred to a polyvinylidene fluoride membrane. After blocking with skim milk,

Genetics and Molecular Research 15 (4): gmr15048978 
the membrane was incubated with NF- $\mathrm{kB}$ and ICAM-1 monoclonal antibodies overnight, followed by incubation with secondary antibodies for $1 \mathrm{~h}$. The membrane was developed by using chemiluminescence (Amersham, Piscataway, NJ, USA) and was exposed in a dark room. The Quantity One 1-D analysis software version 4.6.9 (Bio-Rad Laboratories, Inc., Hercules, CA, USA) was used for the data analysis. The results are presented as relative expression level: the ratio of protein gray value to $\beta$-actin gray value.

\section{Statistical analysis}

SPSS 20.0 was used for the statistical analysis. Measurement data were first assessed using normality test and are reported as means \pm standard deviation. One-way ANOVA with Newman-Keuls multiple comparison post-hoc analysis or least significant difference test was used for the comparison of differences between multiple treatment groups. $\mathrm{P}<0.05$ was considered statistically significant.

\section{RESULTS}

\section{Effect of TPG pretreatment on IS/LV, IS/AAR, and AAR/LV in I/R rat models}

Measures of IS/LV, IS/AAR, and AAR/LV significantly decreased in the TPG pretreatment groups compared to those of the modeling group, in a dose-dependent manner ( $\mathrm{P}$ $<0.05$ ). Group E showed the most significant decrease (Figure 1).

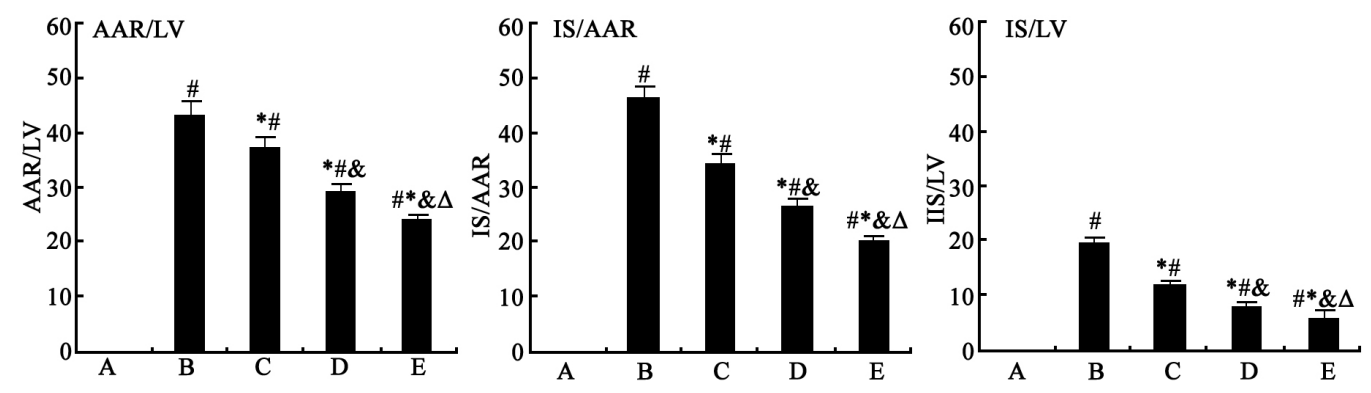

Figure 1. Effect of total peony glucoside (TPG) pretreatment on IS/LV, IS/AAR, and AAR/LV in ischemiareperfusion rat models. A, control; B, model group; C, D, E, 100, 200, $400 \mathrm{mg} / \mathrm{kg}$ TPG pretreatment groups. ${ }^{*} \mathrm{P}<$ 0.05 , compared to group $\mathrm{A} ;{ }^{*} \mathrm{P}<0.05$, compared to group $\mathrm{B} ;{ }^{\circledR} \mathrm{P}<0.05$, compared to group $\mathrm{C}$; ${ }^{\mathrm{D}} \mathrm{P}<0.05$, compared to group D. IS/LV, infarct size in the left ventricle; AAR/LV, area at risk in the left ventricle; IS/AAR, infarct size expressed as a percentage of area at risk.

\section{Effect of TPG pretreatment on serum IL-6 and IL-8 levels in I/R rat models}

Serum IL-6 and IL-8 levels of the group B rats significantly elevated compared to those of the group A rats $(\mathrm{P}<0.05)$, whereas their levels were reduced in the group $\mathrm{C}, \mathrm{D}$, and $\mathrm{E}$ rats, in a dose-dependent manner $(\mathrm{P}<0.05)$. Group $\mathrm{E}$ presented the most obvious reduction (Figure 2). 

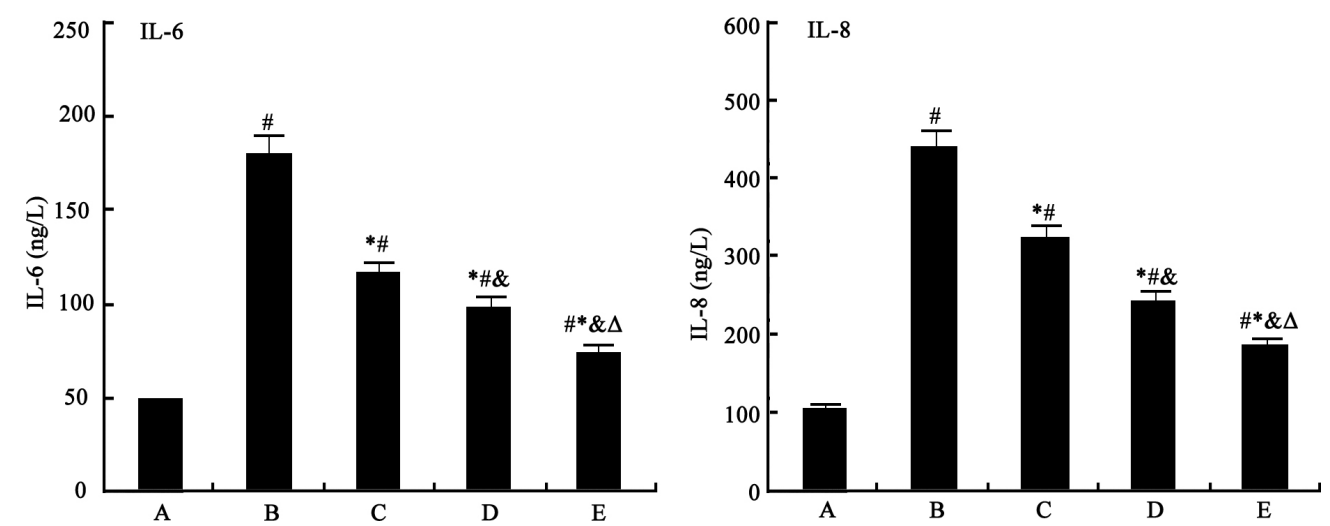

Figure 2. Effect of total peony glucoside (TPG) pretreatment on serum IL-6 and IL-8 levels in ischemia-reperfusion rat models. A, control; B, model group; C, D, E, 100, 200, $400 \mathrm{mg} / \mathrm{kg}$ TPG pretreatment groups, respectively. " $\mathrm{P}<$ 0.05 , compared to group $\mathrm{A} ;{ }^{*} \mathrm{P}<0.05$, compared to group $\mathrm{B}$; ${ }^{\&} \mathrm{P}<0.05$, compared to group $\mathrm{C}$; ${ }^{\mathrm{D}} \mathrm{P}<0.05$, compared to group D. IL-6, interleukin-6; IL-8, interleukin-8.

\section{Effect of TPG pretreatment on NF-кB and ICAM-1 mRNA expressions in myocardial tissue of $\mathrm{I} / \mathrm{R}$ rat models}

mRNA expressions of NF- $\kappa \mathrm{B}$ and ICAM-1 significantly increased in the group B rats compared to those of the group A rats $(\mathrm{P}<0.05)$. However, their levels declined in the TPG groups in a dose-dependent manner (Figure 3).
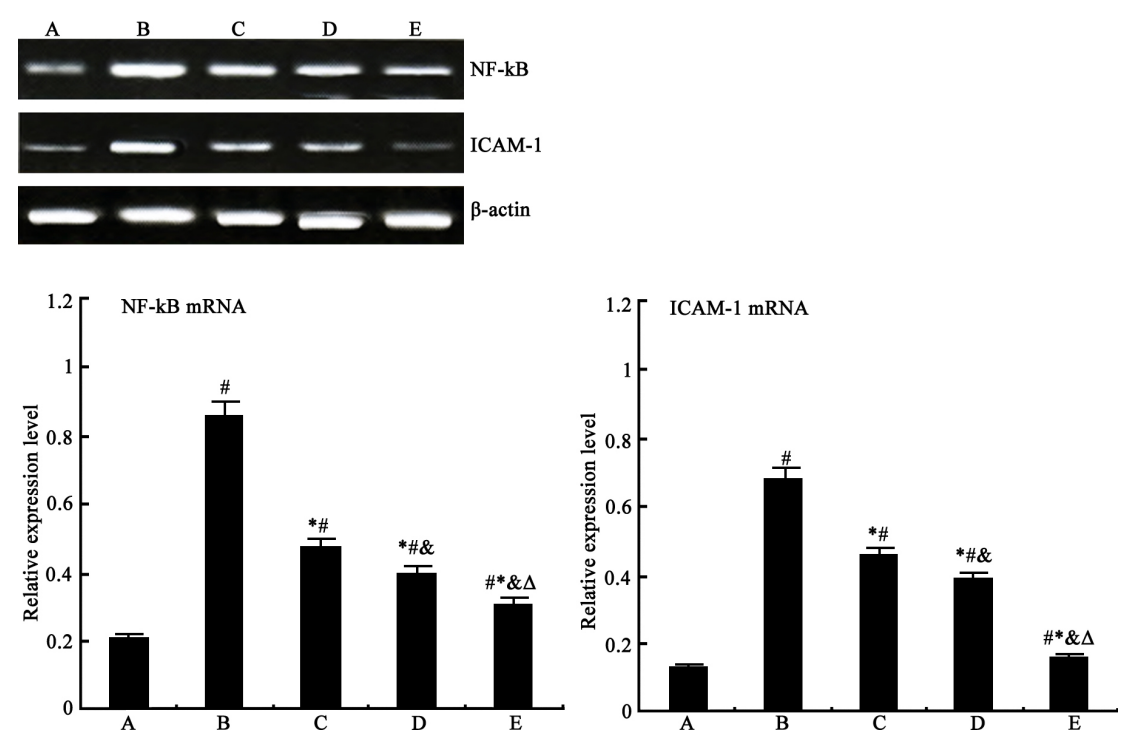

Figure 3. Effect of total peony glucoside (TPG) pretreatment on NF- $\kappa B$ and ICAM-1 mRNA expressions in the myocardial tissue from ischemia-reperfusion rat models. A, control; B, model group; C, D, E, 100, 200, $400 \mathrm{mg} / \mathrm{kg}$ TPG pretreatment groups, respectively. $\beta$-actin was used as a loading control. ${ }^{*} \mathrm{P}<0.05$, compared to group $\mathrm{A}$; $* \mathrm{P}$ $<0.05$, compared to group $\mathrm{B}$; ${ }^{\&} \mathrm{P}<0.05$, compared to group $\mathrm{C}$; ${ }^{\mathrm{D}} \mathrm{P}<0.05$, compared to group $\mathrm{D}$. NF- $\mathrm{KB}$, nuclear factor-kappa B; ICAM-1, intercellular adhesion molecule-1. 


\section{Effect of TPG pretreatment on NF-кB and ICAM-1 protein expressions in myocardial tissue of $\mathrm{I} / \mathrm{R}$ rat models}

Protein expressions of NF- $\mathrm{KB}$ and ICAM-1 were also measured, which showed significant elevation in the group $\mathrm{B}$ rats compared to those of the group A rats $(\mathrm{P}<0.05)$. However, their levels decreased after TPG treatment in a dose-dependent manner (Figure 4).
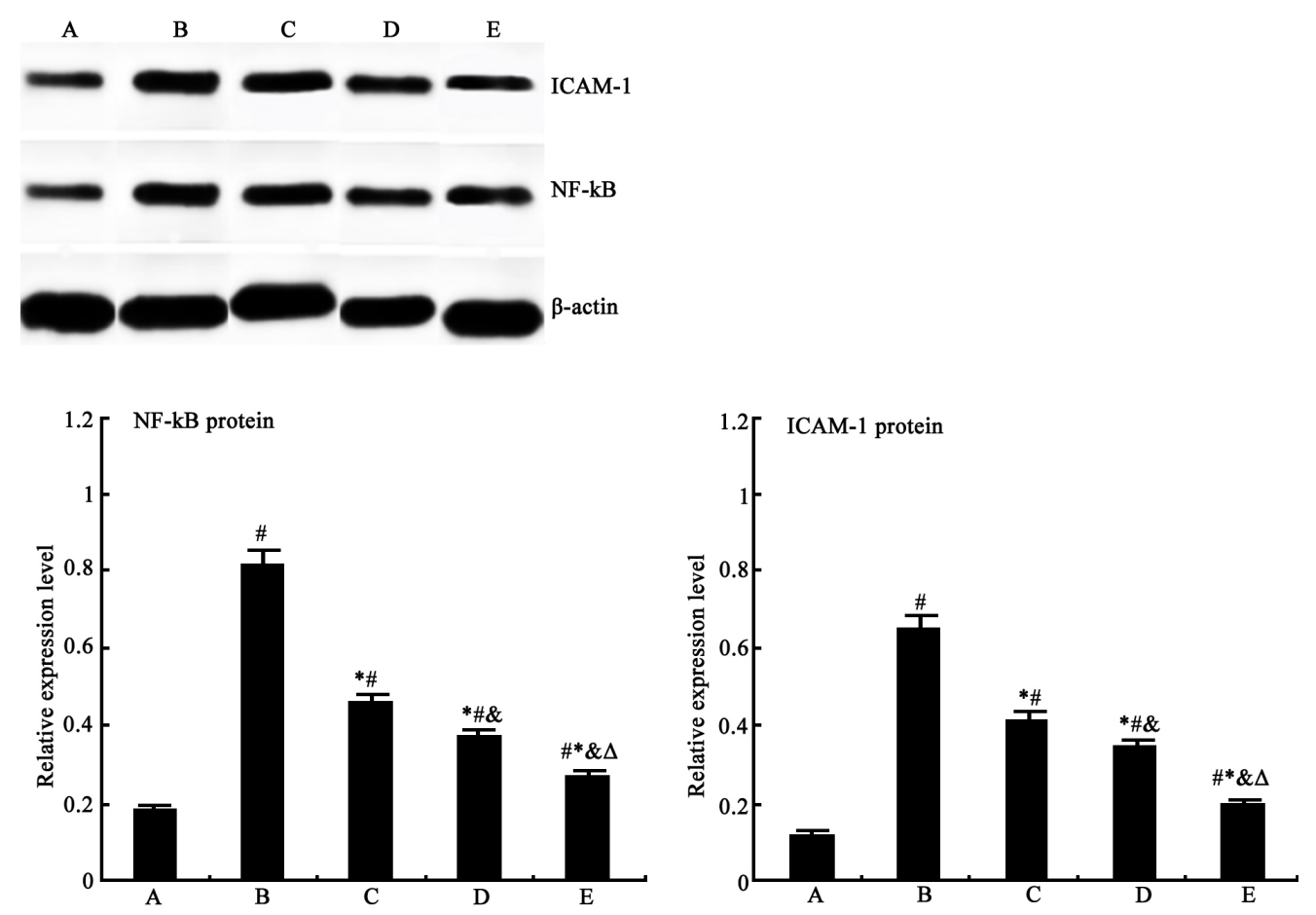

Figure 4. Effect of total peony glucoside (TPG) pretreatment on NF- $\mathrm{KB}$ and ICAM-1 protein expressions in the myocardial tissue from ischemia-reperfusion rat models. A, control; B, model group; C, D, E, 100, 200, $400 \mathrm{mg} / \mathrm{kg}$ TPG pretreatment groups, respectively. $\beta$-actin was used as a loading control. ${ }^{*} \mathrm{P}<0.05$, compared to group A; $* \mathrm{P}$ $<0.05$, compared to group $\mathrm{B}$; ${ }^{\&} \mathrm{P}<0.05$, compared to group $\mathrm{C}$; ${ }^{\mathrm{D}} \mathrm{P}<0.05$, compared to group $\mathrm{D}$. NF- $\mathrm{kB}$, nuclear factor-kappa B; ICAM-1, intercellular adhesion molecule-1.

\section{DISCUSSION}

Myocardial I/R injury is a common pathological condition. The application of thrombolytic therapy, coronary artery bypass surgery, and percutaneous coronary intervention significantly improves the prognosis of patients with acute myocardial infarction. However, myocardial I/R injuries, such as arrhythmia and cell apoptosis, seriously affect the recovery of cardiac function. Alleviation of myocardial I/R injury plays an important role in the treatment of patients with acute myocardial infarction (Shen et al., 2013; Wei et al., 2013; Liang et al., 2014). TPG can inhibit isoprenaline-induced myocardial cell apoptosis in rat with acute myocardial ischemic injury, protect brain affected with pallasiomy brain $\mathrm{I} / \mathrm{R}$, and reduce the 
secretion of cytokines such as tumor necrosis factor- $\alpha$ and ICAM-1 (Long et al., 2012; Jin et al., 2014). This study showed that IS/LV, IS/AAR, and AAR/LV levels significantly decreased in the TPG pretreatment groups compared to those of the modeling group, in a dose-dependent manner, suggesting that TPG can reduce the infarct area. This is consistent with previous studies showing the protective effect of TPG in I/R-affected brain tissue (Long et al., 2012; Jin et al., 2014).

Recently, it was found that inflammation-induced injury also plays critical roles in the pathogenesis of myocardial I/R (Liang et al., 2012; Zeng et al., 2012; Ji et al., 2015). IL-6 is mainly derived from mononuclear macrophages, endothelial cells, vascular smooth muscle cells, and T/B lymphocytes. It can promote ICAM-1 gene expression and induce the infiltration of granulocytes to myocardial ischemic area. ICAM-1 can bind to lymphocyte functionassociated antigen-1, which is expressed on the surface of neutrophils, and lead to the initiation of signal transduction, induction of neutrophil and endothelial cell adhesion, and neutrophil infiltration (Di Paola et al., 2011; Hu et al., 2011). IL-8, a type of chemokine for inflammatory cells ( $\mathrm{T}$ cells and neutrophils), is mainly derived from epithelial cells, macrophages, and neutrophils. IL-6 can stimulate IL-8 production. IL-8 binds to the G-protein-coupled receptors expressed on the cell surface, mediates signal transduction to induce leukocyte adhesion and activation, and promotes white blood cell adhesion to extracellular matrix to release proteolytic enzyme and produce peroxide (Xu et al., 2010; Zhao et al., 2010). Our results revealed that serum IL-6 and IL-8 levels significantly decreased after TPG treatment, indicating that TPG could alleviate inflammation and protect myocardial tissue, possibly through inhibition of the secretion of IL-6 and IL-8 in myocardial I/R rat models.

IL-8 and IL-6 secretions can be regulated by multiple signaling pathways, of which NF$\kappa \mathrm{B}$ is an important pathway involved in myocardial cell hypoxia and ischemia as well as ischemia preadaptation (Yin et al., 2008; Jin et al., 2009). In vitro and in vivo studies have confirmed that NF- $\kappa B$ participates in the pathogenesis of I/R (Gu et al., 2006; Frantz et al., 2007). Generally, $\mathrm{NF}-\kappa \mathrm{B}$ is inactive in the cytoplasm. Once activated, NF- $\kappa \mathrm{B}$ promotes inhibitor of kappa B

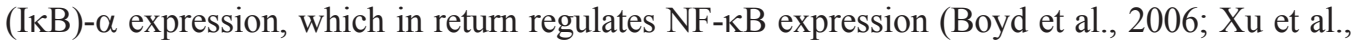

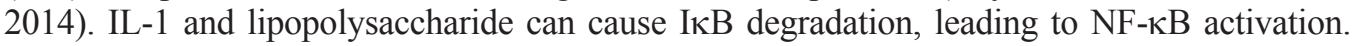
$\mathrm{NF}-\kappa \mathrm{B}$ binds to specific $\kappa \mathrm{B}$ sequence after entering the nucleus to promote the transcription of several inflammatory mediators and cytokines, leading to inflammation. Myocardial ischemia leads to inflammation, whereas reperfusion aggravates inflammation-induced injury.

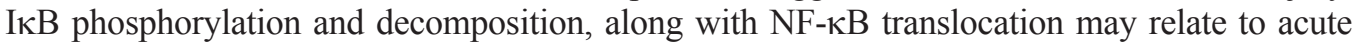
inflammation-induced injury (Frantz et al., 2007; Xu et al., 2014). NF- $\mathrm{\kappa B}$ can bind to various upstream promoters and enhancers of the genes coding ICAM-1 and IL-8, and upregulate their gene expression (Gu et al., 2006; Xu et al., 2014). ICAM-1 is a ligand of the integrin lymphocyte function-associated antigen-1, which promotes endothelial cell and leukocyte adhesion. This study showed high mRNA expressions of NF- $\mathrm{KB}$ and ICAM-1 in the modeling group, but their low expressions in the TPG groups, suggesting that TPG might reduce leukocyte and endothelial cell adhesion and inflammatory reaction by inhibiting the expression of NF- $\kappa B$. Our results also revealed increased protein expressions of NF- $\kappa \mathrm{B}$ and ICAM-1 in the modeling group, but TPG reduced NF- $\mathrm{KB}$ and ICAM-1 protein levels in the myocardial tissue, indicating that the protective effect of TPG on myocardium might be related to the inhibition of NF- $\mathrm{KB}$ signaling pathway and subsequent decrease in the secretion of inflammatory factors.

In conclusion, TPG can protect myocardium from I/R by suppressing I/R-induced NF$\kappa \mathrm{B}$ activation and decreasing the release of inflammatory factors.

Genetics and Molecular Research 15 (4): gmr15048978 


\section{Conflicts of interest}

The authors declare no conflict of interest.

\section{ACKNOWLEDGMENTS}

We thank the anonymous reviewers for reviewing this manuscript.

\section{REFERENCES}

Boyd JH, Mathur S, Wang Y, Bateman RM, et al. (2006). Toll-like receptor stimulation in cardiomyoctes decreases contractility and initiates an NF-kappaB dependent inflammatory response. Cardiovasc. Res. 72: 384-393. http:// dx.doi.org/10.1016/j.cardiores.2006.09.011

Chen JY, Wu HX, Chen Y, Zhang LL, et al. (2012). Paeoniflorin inhibits proliferation of fibroblast-like synoviocytes through suppressing G-protein-coupled receptor kinase 2. Planta Med. 78: 665-671. http://dx.doi.org/10.1055/s-0031-1298327

Di Paola R, Mazzon E, Paterniti I, Impellizzeri D, et al. (2011). Olprinone, a PDE3 inhibitor, modulates the inflammation associated with myocardial ischemia-reperfusion injury in rats. Eur. J. Pharmacol. 650: 612-620. http://dx.doi. org/10.1016/j.ejphar.2010.10.043

Frantz S, Tillmanns J, Kuhlencordt PJ, Schmidt I, et al. (2007). Tissue-specific effects of the nuclear factor kappaB subunit p50 on myocardial ischemia-reperfusion injury. Am. J. Pathol. 171: 507-512. http://dx.doi.org/10.2353/ ajpath.2007.061042

Gu Q, Yang XP, Bonde P, DiPaula A, et al. (2006). Inhibition of TNF-alpha reduces myocardial injury and proinflammatory pathways following ischemia-reperfusion in the dog. J. Cardiovasc. Pharmacol. 48: 320-328. http://dx.doi. org/10.1097/01.fjc.0000250079.46526.38

Hu ZC, Chen YD and Ren YH (2011). Methylprednisolone improves microcirculation in streptozotocin-induced diabetic rats after myocardial ischemia/reperfusion. Chin. Med. J. (Engl.) 124: 923-929.

Ji YY, Wang ZD, Wang SF, Wang BT, et al. (2015). Ischemic preconditioning ameliorates intestinal injury induced by ischemia-reperfusion in rats. World J. Gastroenterol. 21: 8081-8088.

Jin C, Cleveland JC, Ao L, Li J, et al. (2014). Human myocardium releases heat shock protein 27 (HSP27) after global ischemia: the proinflammatory effect of extracellular HSP27 through toll-like receptor (TLR)-2 and TLR4. Mol. Med. 20: 280-289. http://dx.doi.org/10.2119/molmed.2014.00058

Jin YC, Kim CW, Kim YM, Nizamutdinova IT, et al. (2009). Cryptotanshinone, a lipophilic compound of Salvia miltiorrriza root, inhibits TNF-alpha-induced expression of adhesion molecules in HUVEC and attenuates rat myocardial ischemia/reperfusion injury in vivo. Eur. J. Pharmacol. 614: 91-97. http://dx.doi.org/10.1016/j.ejphar.2009.04.038

Liang X, Huang J, Lin X, Qin F, et al. (2014). The effect of 17-methoxyl-7-hydroxy-benzene-furanchalcone on NF- $\mathrm{BB}$ and the inflammatory response during myocardial ischemia reperfusion injury in rats. J. Cardiovasc. Pharmacol. 63: 68-75. http://dx.doi.org/10.1097/FJC.0000000000000027

Liang Z, Liu LF, Yao TM, Huo Y, et al. (2012). Cardioprotective effects of Guanxinshutong (GXST) against myocardial ischemia/ reperfusion injury in rats. J. Geriatr. Cardiol. 9: 130-136. http://dx.doi.org/10.3724/SP.J.1263.2011.11261

Long J, Gao M, Kong Y, Shen X, et al. (2012). Cardioprotective effect of total paeony glycosides against isoprenalineinduced myocardial ischemia in rats. Phytomedicine 19: 672-676. http://dx.doi.org/10.1016/j.phymed.2012.03.004

Lungkaphin A, Pongchaidecha A, Palee S, Arjinajarn P, et al. (2015). Pinocembrin reduces cardiac arrhythmia and infarct size in rats subjected to acute myocardial ischemia/reperfusion. Appl. Physiol. Nutr. Metab. 40: 1031-1037. http:// dx.doi.org/10.1139/apnm-2015-0108

Shen B, Li J, Gao L, Zhang J, et al. (2013). Role of CC-chemokine receptor 5 on myocardial ischemia-reperfusion injury in rats. Mol. Cell. Biochem. 378: 137-144. http://dx.doi.org/10.1007/s11010-013-1604-Z

Wei G, Guan Y, Yin Y, Duan J, et al. (2013). Anti-inflammatory effect of protocatechuic aldehyde on myocardial ischemia/ reperfusion injury in vivo and in vitro. Inflammation 36: 592-602. http://dx.doi.org/10.1007/s10753-012-9581-Z

Wu ZY, Wang ZW, Hu R, Zhou Z, et al. (2015). Role of Nrf2 signal pathway in rats with deep hypothermia ischemia/ reperfusion injury undergoing remote postconditioning. Genet. Mol. Res. 14:492-499. http://dx.doi.org/10.4238/2015. January. 26.2

Wu ZY, Yao Y, Hu R, Dai FF, et al. (2016). Cyclic adenosine monophosphate-protein kinase A signal pathway may be involved in pulmonary aquaporin-5 expression in ischemia/reperfusion rats following deep hypothermia cardiac arrest. Genet. Mol. Res. 15: 15017377. http://dx.doi.org/10.4238/gmr.15017377

Genetics and Molecular Research 15 (4): gmr15048978 
Xu H, Wang D, Peng C, Huang X, et al. (2014). Rabbit sera containing compound danshen dripping pill attenuate leukocytes adhesion to TNF-alpha--activated human umbilical vein endothelial cells by suppressing endothelial ICAM-1 and VCAM-1 expression through NF-kappaB signaling pathway. J. Cardiovasc. Pharmacol. 63: 323-332. http://dx.doi.org/10.1097/FJC.0000000000000046

$\mathrm{Xu}$ HY, Chen ZW and Wu YM (2012). Antitumor activity of total paeony glycoside against human chronic myelocytic leukemia K562 cell lines in vitro and in vivo. Med. Oncol. 29: 1137-1147. http://dx.doi.org/10.1007/s12032-0119909-9

Xu JH, Zhao YY, Wang JK, Yuan ZG, et al. (2010). Effects of mouse recombinant bone morphogenetic protein-7 transfection on cell apoptosis, NF-kappaB, and downstream genes in cultured primary cardiomyocytes after simulated ischemia and reperfusion injury. J. Cardiovasc. Pharmacol. 56: 69-77. http://dx.doi.org/10.1097/FJC.0b013e3181e0badc

Yin H, Chao L and Chao J (2008). Nitric oxide mediates cardiac protection of tissue kallikrein by reducing inflammation and ventricular remodeling after myocardial ischemia/reperfusion. Life Sci. 82: 156-165. http://dx.doi.org/10.1016/j. Ifs.2007.10.021

Zeng M, Yan H, Chen Y, Zhao HJ, et al. (2012). Suppression of NF-אB reduces myocardial no-reflow. PLoS One 7: e47306. http://dx.doi.org/10.1371/journal.pone.0047306

Zhao N, Liu YY, Wang F, Hu BH, et al. (2010). Cardiotonic pills, a compound Chinese medicine, protects ischemiareperfusion-induced microcirculatory disturbance and myocardial damage in rats. Am. J. Physiol. Heart Circ. Physiol. 298: H1166-H1176. http://dx.doi.org/10.1152/ajpheart.01186.2009 